\title{
Proteinuria in cystic fibrosis: a possible correlation between genotype and renal phenotype***
}

\author{
Proteinúria na fibrose cística: possível \\ correlação entre genótipo e fenótipo renal \\ Jessica Cemlyn-Jones, Fernanda Gamboa
}

\begin{abstract}
Objective: To assess proteinuria in patients with cystic fibrosis (CF), and to correlate proteinuria with genotype, CF-related diabetes and disease severity. Methods: A prospective study was carried out over a six-month period and involving $22 \mathrm{CF}$ patients. After the collection and analysis of 24-h urine samples, the patients were divided into two subgroups: protein excretion < $150 \mathrm{mg} /$ day (low-proteinuria); and protein excretion $\geq 150 \mathrm{mg} /$ day (highproteinuria). Patient charts were reviewed to obtain data on genotype and CF-related diabetes. Disease severity was assessed based on acute exacerbations in the last six months and FEV , measured during the study period. To assess the correlation between genotype and proteinuria, the two main mutations ( $\triangle \mathrm{F} 508$ and R334W) were evaluated. Due to the existence of genotype $\Delta \mathrm{F} 508 / \mathrm{R} 334 \mathrm{~W}$, two categories were created to enable statistical analysis, $\Delta \mathrm{F} 508$ being evaluated in category 1 and R334W being evaluated in category 2. Results: The $\Delta \mathrm{F} 508$ mutation tended to be associated with normal protein excretion: 100\% of the low-proteinuria subgroup patients were considered $\Delta \mathrm{F} 508$ in category 1 , compared with $86.7 \%$ in category 2 . Protein excretion tended to be higher in patients with the R334W mutation: $60.0 \%$ of the high-proteinuria subgroup patients were considered R334W in category 1 , compared with $80.0 \%$ in category $2(p=0.009$ and $p=0.014$, respectively). No significant association was found for any of the other variables. Conclusions: The results suggest that genotype is associated with renal phenotype, depending on the mechanism by which the genotype alters the function of the cystic fibrosis transmembrane conductance regulator gene.
\end{abstract}

Keywords: Proteinuria; Cystic fibrosis; Genotype.

\section{Resumo}

Objetivo: Avaliar a proteinúria em pacientes com fibrose cística $(\mathrm{FC})$ e correlacioná-la com o genótipo, com a diabetes relacionada à FC e com a gravidade da doença. Métodos: Estudo prospectivo realizado num período de seis meses com 22 pacientes com FC. Efetuada proteinúria de $24 \mathrm{~h}$ com a divisão dos pacientes em dois subgrupos: proteinúria < $150 \mathrm{mg} /$ dia (proteinúria-baixa); e proteinúria $\geq 150 \mathrm{mg} /$ dia (proteinúria-alta). Revisamos os prontuários clínicos para a coleta de informações sobre o genótipo e a presença de diabetes relacionada à FC. A gravidade da doença foi avaliada pelas exacerbações agudas no último semestre e pelo $\mathrm{VEF}_{1}$ durante o período de estudo. Para avaliar a correlação entre genótipo e proteinúria, consideraram-se as duas principais mutações, $\Delta$ F508 e R334W. Dada a existência do genótipo $\Delta \mathrm{F} 508 / \mathrm{R} 334 \mathrm{~W}$, foram criadas duas categorias para se proceder à avaliação estatística, sendo esse genótipo considerado $\Delta \mathrm{F} 508$ na categoria 1 e R334W na categoria 2. Resultados: A mutação $\Delta \mathrm{F} 508$ se associou com valores normais de proteinúria: $100 \%$ dos pacientes do subgrupo proteinúria-baixa foram considerados $\Delta \mathrm{F} 508$ na categoria 1 , comparados a $86,7 \%$ na categoria 2 . Em pacientes com a mutação R334W, os valores de proteinuria foram mais elevados: $60,0 \%$ dos pacientes do subgrupo proteinúria-alta foram considerados R334W na categoria 1 , comparados a $80,0 \%$ na categoria 2 ( $p=0,009$ e $p=0,014$, respectivamente). Para as outras variáveis, não houve associação significativa. Conclusões: Os resultados sugerem que há uma associação entre o genótipo e o fenótipo renal, dependendo do mecanismo pelo qual o genótipo altera a função do gene regulador de condutância transmembrana da fibrose cística.

Descritores: Proteinúria; Fibrose cística; Genótipo.

\footnotetext{
* Study carried out in the Department of Pulmonology and Allergology of the Hospitals of the University of Coimbra, Coimbra, Portugal.

Correspondence to: Jessica Cemlyn-Jones. Av. Calouste de Gulbenkian, 98, 5 posterior, 3001-090, Coimbra, AC, Portugal. Tel 0035196 153-6275. E-mail: jcemlynjones@yahoo.com

Financial support: None.

Submitted: 22 October 2008. Accepted, after review: 18 February 2009.

** A versão completa em português deste artigo está disponivel em www.jornaldepneumologia.com.br
} 


\section{Introduction}

Cystic fibrosis (CF) is the most common fatal autosomal recessive disease among White people and is caused by mutations in a single gene known as the cystic fibrosis transmembrane conductance regulator (CFTR) gene, a complex chloride channel found in all exocrine tissues.

More than 1,300 CFTR gene mutations have been reported to the Cystic Fibrosis Genetic Analysis Consortium. ${ }^{(1)}$ These mutations fall into five classes based on their effect on protein structure or function ${ }^{(1)}$; class 1 mutations lead to the disruption of the CFTR protein synthesis; class 11 mutations are associated with defective protein processing; class 111 mutations lead to the production of proteins that reach the plasma membrane but with defective regulation, which prevents them from being activated; class IV mutations are associated with altered conductance such that the rate of chloride transport is reduced; and class $\mathrm{V}$ mutations lead to the production of normal proteins but at reduced levels. Class 1, 11 and 111 mutations are considered severe.

The $\Delta$ F508 mutation is a class 11 mutation and accounts for approximately 70\% of chromosomes in CF patients. The majority of the other CFTR mutations are quite rare. ${ }^{(2)}$

The clinical spectrum of CF is highly variable, ranging from severe disease with pancreatic insufficiency and early lung involvement to a much milder form. ${ }^{(3)}$ There appears to be a relatively strong correlation between the CFTR gene mutation and the phenotype in the pancreas and gastrointestinal tract, although this correlation is much weaker in the lung. Little is known about this correlation in the kidney. ${ }^{(4)}$ Patients with pancreatic sufficiency have at least one mild allele (a class IV mutation, partial missplicing of a class 1 mutation or a mutation affecting protein stability), whereas patients with pancreatic insufficiency are homozygous or compound heterozygous for two severe (class 1, 11 or 111) mutations. The pulmonary component of $\mathrm{CF}$ is highly variable, even among siblings with identical mutations. Recent reports have demonstrated a correlation between certain mutations and the severity of lung disease. ${ }^{(5)}$ However, it still seems that CFTR mutations have a more variable impact on the pulmonary phenotype, in which modifier genes and environmental effects also contribute to disease severity. ${ }^{(6)}$
The CFTR gene is abundantly expressed in all nephron segments. However, there seems to be no clear renal phenotype and no major primary renal dysfunction. Renal abnormalities in CF tend to be due either to secondary causes or to associated conditions. These include exposure to aminoglycosides and other nephrotoxic antibiotics or drugs, as well as immune complex-mediated injury in the presence of chronic bacterial infection, diabetes mellitus, liver disease, cor pulmonale, malabsorption or steatorrhea. Hypoxemia in severe lung disease can increase the nephrotoxic potentials of these risk factors. ${ }^{(7)}$

In recent years, reports of renal disease in CF patients have been increasing, although there is still a shortage of clinical reporting. The following alterations have all been described in CF patients: glomerulosclerosis; immune complex deposition; lgA nephropathy; mesangial proliferation; nephrocalcinosis; microscopic hematuria; tubular injury; diabetic nephropathy; fibrillary glomerulonephritis; and amyloidosis. Aberrant CFTR expression might explain the subtle abnormalities in renal concentrating and diluting ability described in $\mathrm{CF}$, as well as the increased incidence of nephrocalcinosis. ${ }^{(8)}$ Recent studies have suggested that the loss of CFTR gene function interferes with the handling of low-molecular-weight proteins through impairment of receptor mediator endocytosis in proximal tubule cells, thereby leading to selective proteinuria. ${ }^{(9)}$ However, CFTR gene expression and processing in the kidney is not fully understood, and no predominant renal phenotype has yet been documented in CF patients.

In one study, it was reported that 5 of the 23 patients evaluated in an autopsy series had

Table 1 - Demographic and clinical characteristics of the cystic fibrosis patients evaluated.

\begin{tabular}{lc}
\hline \multicolumn{1}{c}{ Characteristic } & $\begin{array}{c}\text { Study group } \\
(\mathrm{n}=22)\end{array}$ \\
\hline Age in years, mean \pm SD (range) & $25 \pm 6(14-35)$ \\
Gender & $15(68)$ \\
$\quad$ Female, $\mathrm{n}(\%)$ & $7(32)$ \\
$\quad$ Male, $\mathrm{n}(\%)$ & $22(100)$ \\
Chronic bacterial colonization, $\mathrm{n}(\%)$ & $5(23)$ \\
Cystic fibrosis-related diabetes, $\mathrm{n}(\%)$ & $6(27)$ \\
Acute exacerbation in last 6 months, & \\
$\mathrm{n}(\%)$ & $8(36)$ \\
FEV $_{1} \leq 50 \%, \mathrm{n}(\%)$ & \\
\hline
\end{tabular}


a history of unexplained proteinuria in routine analysis, and that the majority of these patients presented renal pathology at autopsy. ${ }^{(10)}$

In CF patients, urinalysis often reveals mild proteinuria. ${ }^{(11)}$ However, some of the case studies in this field have reported relevant issues, including the fact that CF patients with renal disease can present significant proteinuria, although kidney function (blood urea nitrogen and creatinine) can be normal. ${ }^{(12)}$ Proteinuria progressing to nephrotic syndrome has an extremely poor prognosis. ${ }^{(13,14)}$

In healthy persons, mean urinary protein excretion is $60-80 \mathrm{mg}$, with an upper limit of $150 \mathrm{mg} /$ day. $^{(7)}$ Current evidence indicates that proteinuria is an early marker of an increased risk of progressive kidney disease, poor cardiovascular outcome and death. Among the various predictors of progression of chronic kidney disease to end stage renal disease, proteinuria is the most important. ${ }^{(15,16)}$ In CF patients, urinalysis can be helpful, and proteinuria should raise the suspicion of CF-related renal disease. However, renal biopsies are rarely performed, which seems to suggest that isolated proteinuria is not sufficient to prompt histological confirmation.

The aim of this study was to assess protein excretion in a population of CF patients, as well as to determine whether protein excretion correlates with genotype, cystic fibrosis-related diabetes (CFRD) and disease severity.

Since the exact prevalence of proteinuria is not known in the general population, 24-h protein excretion was also evaluated in a group of healthy controls.

\section{Methods}

This was a prospective study of adult CF patients treated in the Department of Pulmonology and Allergology of the Hospitals of the University of Coimbra, located in the city of Coimbra, Portugal, over a period of six months. Of the 24 CF patients treated during that period, 2 were also lung transplant patients and were excluded, since the pharmacological treatment

Table 2 - Clinical variables, by individual genotype, for the 22 cystic fibrosis patients evaluated.

\begin{tabular}{|c|c|c|c|c|}
\hline \multirow[t]{3}{*}{ Patient genotype } & \multicolumn{4}{|c|}{ Variable } \\
\hline & \multirow{2}{*}{$\frac{\text { Protein excretion }}{(\mathrm{mg} / 24 \mathrm{~h})}$} & \multirow[t]{2}{*}{ CFRD } & \multirow{2}{*}{$\begin{array}{l}\text { Acute exacerbations } \\
\text { in the last } 6 \text { months }\end{array}$} & $\mathrm{FEV}_{1}$ \\
\hline & & & & $(\%)$ \\
\hline A516E/A516E & 156 & yes & yes & 20.7 \\
\hline$\Delta \mathrm{F} 508 / \Delta \mathrm{F} 508$ & 92 & no & yes & 22 \\
\hline$\Delta \mathrm{F} 508 / \Delta \mathrm{F} 508$ & 77.3 & no & no & 111 \\
\hline$\Delta \mathrm{F} 508 / \Delta \mathrm{F} 508$ & 62.7 & no & no & 79.0 \\
\hline$\Delta \mathrm{F} 508 / \Delta \mathrm{F} 508$ & 73.5 & no & no & 73.7 \\
\hline$\Delta \mathrm{F} 508 / \Delta \mathrm{F} 508$ & 84 & yes & yes & 39.2 \\
\hline$\Delta \mathrm{F} 508 / \Delta \mathrm{F} 508$ & 128.8 & yes & no & 71.1 \\
\hline$\Delta \mathrm{F} 508 / \Delta \mathrm{F} 508$ & 132 & no & no & 58.4 \\
\hline$\Delta \mathrm{F} 508 / \Delta \mathrm{F} 508$ & 160 & no & no & 87.9 \\
\hline$\Delta \mathrm{F} 508 / \Delta \mathrm{F} 508$ & 76.5 & yes & no & 63.0 \\
\hline$\Delta \mathrm{F} 508 / \Delta \mathrm{F} 508$ & 80 & no & no & 48.8 \\
\hline$\Delta \mathrm{F} 508 / \mathrm{P} 205 \mathrm{~S}$ & 78 & no & no & 81 \\
\hline$\Delta \mathrm{F} 508 / \mathrm{P} 205 \mathrm{~S}$ & 143.4 & no & no & 54.0 \\
\hline$\Delta \mathrm{F} 508 / \mathrm{P} 205 \mathrm{~S}$ & 88.8 & no & no & 112.7 \\
\hline$\Delta \mathrm{F} 508 / \mathrm{R} 1066 \mathrm{C}$ & 70 & no & yes & 42.3 \\
\hline$\Delta \mathrm{F} 508 / \mathrm{R} 334 \mathrm{~W}$ & 73.9 & no & no & 40 \\
\hline$\Delta \mathrm{F} 508 / \mathrm{R} 334 \mathrm{~W}$ & 184.5 & no & no & 79.6 \\
\hline$\Delta \mathrm{F} 508 / \mathrm{R} 334 \mathrm{~W}$ & 133.2 & no & no & 98.6 \\
\hline$\Delta \mathrm{F} 508 \mathrm{del} / \mathrm{NIM}$ & 134.6 & yes & no & 98 \\
\hline R334W/R334W & 179 & no & no & 63.0 \\
\hline R334W/R334W & 156 & no & yes & 33.8 \\
\hline R334W/R334W & 949 & no & yes & 50.4 \\
\hline
\end{tabular}

CFRD: cystic fibrosis-related diabetes. 
for lung transplant can influence renal function. Therefore, the final study sample consisted of $22 \mathrm{CF}$ patients. We also recruited a group of 22 healthy adult controls composed of doctors, nurses and family members of Department staff.

After the objective of the study had been explained to all of the participants, 24-h urine samples, each including an overnight sample, ${ }^{(17)}$ were collected. Samples were not collected when patients had infectious exacerbations or had recently received intravenous aminoglycosides.

Since mild proteinuria is frequently found in CF patients, the study group was divided into two subgroups, based on a protein excretion cut-off value of $150 \mathrm{mg} / 24 \mathrm{~h}$ : protein excretion < $150 \mathrm{mg} /$ day (low-proteinuria subgroup); and protein excretion $\geq 150 \mathrm{mg} /$ day (high-proteinuria subgroup).

In all CF patients, genotyping is carried out at initial diagnosis, and an oral glucose tolerance test, including fasting glycemia and measurement of glycemia after ingestion of glucose solution (maximum, $75 \mathrm{~g}$ ), is performed annually to screen for CFRD. Patient records were reviewed in order to obtain these data.

Patients participating in the present study were submitted to spirometry, and we considered $\mathrm{FEV}_{1}<50 \%$ a marker of impaired lung function. ${ }^{(18,19)}$ Having presented infectious exacerbations in the last six months was considered an indicator of disease severity. ${ }^{(20)}$

To assess the correlation between genotype and protein excretion, the two main CFTR gene mutations $(\Delta \mathrm{F} 508$ and $\mathrm{R} 334 \mathrm{~W})$ were evaluated. Due to the existence of the $\Delta \mathrm{F} 508 / \mathrm{R} 334 \mathrm{~W}$ genotype, two categories were created to enable accurate statistical analysis, $\Delta \mathrm{F} 508$ being evaluated in category 1 and R334W being evaluated in category 2.

Cases in which the patient carried neither the $\Delta$ F508 nor the R334W genotype were excluded, as were those in which the patient carried an unidentified mutation. Consequently, the final number of genotypes evaluated in each category was 20 .

\section{Statistical analysis}

Data were analyzed using the program Statistical Package for the Social Sciences, version 15.0 (SPSS Inc, Chicago, IL, USA). Frequency distribution was obtained for the
Table 3 - Distribution according to 24-h urinary protein excretion and genotype frequency.

\begin{tabular}{|c|c|c|c|}
\hline $\begin{array}{c}\text { Patient } \\
\text { subgroup }\end{array}$ & Genotype & $\begin{array}{c}\text { Frequency } \\
\text { (n) }\end{array}$ & $\begin{array}{c}\text { Within } \\
\text { subgroup (n) }\end{array}$ \\
\hline \multirow{6}{*}{$\begin{array}{l}\text { Low- } \\
\text { proteinuria }\end{array}$} & $\Delta \mathrm{F} 508 / \Delta \mathrm{F} 508$ & 9 & 56.3 \\
\hline & $\Delta \mathrm{F} 508 / \mathrm{P} 205 \mathrm{~S}$ & 3 & 18.8 \\
\hline & $\Delta \mathrm{F} 508 / \mathrm{R} 1066 \mathrm{C}$ & 1 & 6.3 \\
\hline & $\Delta \mathrm{F} 508 / \mathrm{R} 334 \mathrm{~W}$ & 2 & 12.5 \\
\hline & $\Delta \mathrm{F} 508 \mathrm{del} / \mathrm{NIM}$ & 1 & 6.3 \\
\hline & Total & 16 & 100.0 \\
\hline \multirow{5}{*}{$\begin{array}{l}\text { High- } \\
\text { proteinuria }\end{array}$} & A516E/A516E & 1 & 16.7 \\
\hline & $\Delta \mathrm{F} 508 / \Delta \mathrm{F} 508$ & 1 & 16.7 \\
\hline & $\Delta \mathrm{F} 508 / \mathrm{R} 334 \mathrm{~W}$ & 1 & 16.7 \\
\hline & R334W/R334W & 3 & 50.0 \\
\hline & Total & 6 & 100.0 \\
\hline
\end{tabular}

Low-proteinuria: $24-\mathrm{h}$ protein excretion $<150 \mathrm{mg} /$ day; and High-proteinuria: 24 -h protein excretion $\geq 150 \mathrm{mg} /$ day.

various qualitative variables. Mean and standard deviation were calculated for quantitative variables. Differences between subgroups were analyzed using Pearson's chi-square test or Fisher's exact test for qualitative variables and the Mann-Whitney test (for two independent samples) for quantitative variables.

To assess differences between the subgroups, considering genotype categories, Pearson's chi-square test or Fisher's exact test was used. Values of $p<0.05$ were considered statistically significant.

Table 4 - Genotype frequency by category, stratified according to $\Delta \mathrm{F} 508$ and R334W mutations.

\begin{tabular}{ccc}
\hline Genotype category & Valid genotype & Frequency $(\mathrm{n})$ \\
\hline Category $1(\mathrm{n}=20)$ & & \\
R334W & R334W/R334W & 3 \\
& Total & 3 \\
$\Delta$ F508 & F508/F508 & 10 \\
& F508/P205S & 3 \\
& F508/R334W & 3 \\
& F508/R1066C & 1 \\
Category 2 $(\mathrm{n}=20)$ & Total & 17 \\
R334W & & \\
& R334W/R334W & 3 \\
& F508/R334W & 3 \\
& Total & 6 \\
$\Delta$ F508 & F508/F508 & 10 \\
& F508/P205S & 3 \\
& F508/R1066C & 1 \\
& Total & 14 \\
\hline
\end{tabular}


Table 5 - Subgroup analysis according to 24 -h proteinuria in relation to genotype category, cystic fibrosisrelated diabetes, disease severity and pulmonary function.

\begin{tabular}{|c|c|c|c|c|}
\hline \multirow[t]{3}{*}{ Variable } & \multirow[t]{2}{*}{ Total } & \multicolumn{2}{|c|}{ Subgroup } & \multirow[t]{3}{*}{$p$} \\
\hline & & $\begin{array}{l}\text { Low-proteinuria } \\
(<150 \mathrm{mg} / \text { day })\end{array}$ & $\begin{array}{l}\text { High-proteinuria } \\
(\geq 150 \mathrm{mg} / \text { day })\end{array}$ & \\
\hline & $22(100)$ & 16 (72.7) & $6(27.3)$ & \\
\hline \multicolumn{5}{|l|}{ Genotype category } \\
\hline \multicolumn{5}{|l|}{ Category 1} \\
\hline$\Delta \mathrm{F} 508, \mathrm{n}(\%)$ & & $15(100.0)$ & $2(40.0)$ & 0.009 \\
\hline R334W, n (\%) & & $0(0.0)$ & $3(60.0)$ & \\
\hline \multicolumn{5}{|l|}{ Category 2} \\
\hline$\Delta \mathrm{F} 508, \mathrm{n}(\%)$ & & $13(86.7)$ & $1(20.0)$ & 0.014 \\
\hline R334W, n (\%) & & $2(13.3)$ & $4(80.0)$ & \\
\hline CFRD, n (\%) & $5(23)$ & $4(25)$ & $1(16.7)$ & 0.399 \\
\hline $\begin{array}{l}\text { Acute exacerbations in } \\
\text { the last } 6 \text { months, } n(\%)\end{array}$ & $6(27)$ & $3(18.8)$ & $3(50)$ & 0.366 \\
\hline $\mathrm{FEV}_{1}<50 \%, \mathrm{n}(\%)$ & $8(36)$ & $5(31.3)$ & $3(50)$ & 0.381 \\
\hline
\end{tabular}

CFRD: cystic fibrosis-related diabetes.

\section{Results}

Patient demographic data are shown in Table 1. The mean age was $25 \pm 6$ years in the $\mathrm{CF}$ group and $24 \pm 6$ years in the control group.

Of the $22 \mathrm{CF}$ patients evaluated, $5(22 \%)$ had CFRD. All 22 patients had chronic bacterial colonization, 6 (27\%) had experienced one or more acute exacerbations requiring management with intravenous antibiotics in the last six months, and $8(36 \%)$ had an $\mathrm{FEV}_{1}<50 \%$.

The mean urinary protein excretion among the CF patients was $150.6 \pm 182.6 \mathrm{mg} / 24 \mathrm{~h}$, with a 5\% trimmed mean of $114.95 \mathrm{mg} / \mathrm{dL}$ (95\% Cl: 69.66-231.54), compared with $89.08 \pm$ $26.64 \mathrm{mg} / 24 \mathrm{~h}$, with a 5\% trimmed mean of $87.45 \mathrm{mg} / \mathrm{dL}$ (95\% Cl: 72.77-100.89), among the controls.

A statistically significant difference was found between the CF group and the control group in terms of mean urinary protein excretion $(\mathrm{p}<0.05)$.

Table 2 shows the clinical variables, by individual genotype, for each of the $22 \mathrm{CF}$ patients evaluated.

Among the $22 \mathrm{CF}$ group patients, protein excretion was $\geq 150 \mathrm{mg} /$ day in $6(27.3 \%), 1$ of whom had significant proteinuria ( $949 \mathrm{mg} /$ day). Another of those 6 also had CFRD. There were 8 CF group patients (36.4\%) with an $\mathrm{FEV}_{1} \leq 50 \%$, and protein excretion was $\geq 150 \mathrm{mg} /$ day in 3 of those patients. The patient who presented protein excretion of $949 \mathrm{mg} /$ day was submitted to renal biopsy. Histological analysis of the biopsy sample revealed mesangioproliferative glomerulonephritis with lgM deposition.

There were 16 patients in the low-proteinuria subgroup and 6 patients in the high-proteinuria subgroup. The frequency of genotypes in each subgroup is shown in Table 3.

All patients who were R334W/R334W homozygotes were in the high-proteinuria subgroup. In the low-proteinuria subgroup, 9 patients were $\Delta \mathrm{F} 508 / \Delta \mathrm{F} 508$ homozygotes (56.3\% within the subgroup). There was only one $\Delta \mathrm{F} 508 / \Delta \mathrm{F} 508$ homozygote in the highproteinuria subgroup.

The categorical analysis of the two main mutations $(\Delta \mathrm{F} 508$ and $\mathrm{R} 334 \mathrm{~W})$ is shown in Table 4. The two cases already mentioned (A516E/A516E and F508del/NIM) were not included in either category.

As can be seen in Table 5 , the $\Delta$ F508 mutation tends to be associated with normal protein excretion. In the low-proteinuria subgroup, all patients were $\Delta \mathrm{F} 508$ in the category 1 analysis, and $86.7 \%$ were $\Delta \mathrm{F} 508$ in the category 2 analysis. In patients with the R334W mutation, protein excretion tended to be higher. In the high-proteinuria subgroup, $60 \%$ of the patients were R334W in the category 1 analysis, compared with $80 \%$ in the category 2 analysis ( $p=0.009$ for category 1 and $p=0.014$ for category 2). No significant relationship was found between 
the two subgroups in terms of CFRD or disease severity.

\section{Discussion}

The class 11 mutations $\Delta \mathrm{F} 508$ and $\mathrm{R} 1066 \mathrm{C}$ are associated with defective protein processing, resulting in CFTR protein synthesis that fails to reach the apical membrane. ${ }^{(1)}$ The class IV mutations R334W and P205S produce a cyclic adenosine monophosphate-responsive channel with reduced conductance, thereby reducing chloride transport. ${ }^{(21)}$

In the present study, the patients with the $\Delta$ F508 mutation presented lower protein excretion than did those with the R334W mutation $(p<0.05)$. Protein excretion was normal in $90 \%$ of the patients who were homozygous for $\Delta \mathrm{F} 508$ and in $100 \%$ of those with the $\Delta \mathrm{F} 508 / \mathrm{P} 205 \mathrm{~S}$ genotype. In the category 1 analysis, $66.7 \%$ of the patients with the $\Delta \mathrm{F} 508 / \mathrm{R} 334 \mathrm{~W}$ genotype also presented protein excretion $<150 \mathrm{mg} / \mathrm{dL}$. Homozygosity for the R334W mutation seems to predispose to higher protein excretion (all R334W/R334W homozygotes were in the highproteinuria subgroup). In fact, the highest protein excretion observed (949 $\mathrm{mg} /$ day) was in one of the R334W/R334W homozygotes.

All of the CF group patients had chronic bacterial colonization. Lung injury due to postcolonization tissue inflammation leads to the increased cytokine levels that precede lung function impairment. Elevated cytokine levels stimulate bone resorption, which might be a contributing factor to the association between decreased FEV and low bone mineral density reported in the CF population. ${ }^{(22)}$ Likewise, immune complex-mediated injury in the presence of chronic bacterial infection can impair renal function. ${ }^{(23)}$ However, in the present study, disease severity, based on FEV values and infectious exacerbations in the last six months, did not correlate with proteinuria $(p=0.366)$. This might be partly explained by the fact that, even in the patients with severe disease, there was no significant exposure to aminoglycosides. One patient had received intravenous tobramycin due to an acute episode, after which protein excretion returned to normal $(70 \mathrm{mg} / \mathrm{dL})$.

No association was found between high protein excretion and CFRD ( $p=0.399)$, protein excretion being $\geq 150 \mathrm{mg} / \mathrm{dL}$ in only one case of CFRD. This might be explained by the fact that, although microalbuminuria is a sensitive indicator of progression to diabetic nephropathy in non-CF diabetes, it is less sensitive for $\mathrm{CF}$ patients, due to confounding factors. ${ }^{(24)}$ Further studies are required in order to clarify whether microalbuminuria is a useful tool for predicting progression to diabetic nephropathy in subjects with CFRD and whether this notion could be extrapolated to proteinuria as a screening tool for CF-related renal disease.

The overall treatment now given to children with CF from the time of diagnosis has notably increased their life expectancy. ${ }^{(25)}$ The selection of candidates for transplant is crucial for their long term survival, and there is a growing emphasis on prevention of complications in organs other than the lung. Increased survival has emphasized the importance of liver disease, which is now the third leading cause of death among adults with CF. ${ }^{(26)}$ Recent reports suggest that focused care and adequate screening have contributed to maintaining clinical stability in adult CF patients with liver abnormalities. ${ }^{(27)}$ Few studies have addressed the prevalence and natural history of renal disease in adults with CF. However, clinical reporting of renal abnormalities is increasing, and the determination of urinary protein excretion could prove useful in identifying $\mathrm{CF}$ patients at risk for progressive renal injury.

In the present study, we found a positive correlation between protein excretion and genotype in CF patients. This suggests that renal phenotype is associated with CFTR gene mutation, perhaps according to the mechanism by which each mutation disrupts CFTR function.

In the routine evaluation of renal function in CF patients, special attention is now given to R334W genotypes. We recommend that 24-h urinary protein excretion be measured on an annual basis in all CF patients. Those in whom protein excretion is $\geq 150 \mathrm{mg} / \mathrm{dL}$ should undergo further testing. If serum creatinine is > $1.4 \mathrm{mg} / \mathrm{dL}$, abdominal ultrasound is indicated, and patients with significant proteinuria (> $1 \mathrm{~g} /$ day) should be submitted to renal biopsy.

\section{Acknowledgments}

The authors would like to thank Dr. Beatriz Tavares (Department of Allergology) for assisting in the data analysis, as well as Dr. Alexandra 
Catarino and Dr. Sara Freitas (Department of Pulmonology) for reviewing the text. The authors are also grateful to all the study participants (patients and controls).

\section{References}

1. Nissim-Rafinia M, Kerem B, Kerem E. Molecular biology of cystic fibrosis: CFTR processing and functions, and classes of mutations. In: Hodson M, Geddes D, Bush A, editors. Cystic Fibrosis. London: Hodder Arnold; 2007. p 49-58.

2. Rowntree RK, Harris A. The phenotypic consequences of CFTR mutations. Ann Hum Genet. 2003;67(Pt 5):471-85.

3. Davies J. Genotype-phenotype correlations and modifier genes. In: Hodson M, Geddes D, Bush A, editors. Cystic Fibrosis. London: Hodder Arnold; 2007. p 81-85

4. Lim M, Zeitlin PL. Therapeutic strategies to correct malfunction of CFTR. Paediatr Respir Rev. 2001;2(2):159-64.

5. Zielenski J. Genotype and phenotype in cystic fibrosis. Respiration. 2000;67(2):117-33.

6. Zielenski J, Tsui LC. Cystic fibrosis: genotypic and phenotypic variations. Annu Rev Genet. 1995;29:777-807.

7. Gyi K. Other System Disorders in Cystic Fibrosis. In: Hodson M, Geddes D, Bush A, editors. Cystic Fibrosis. London: Hodder Arnold; 2007. p 269-77

8. Katz SM, Krueger LJ, Falkner B. Microscopic nephrocalcinosis in cystic fibrosis. $\mathrm{N}$ Engl $\mathrm{J}$ Med. 1988;319(5):263-6.

9. Jouret F, Devuyst 0. CFTR and defective endocytosis: new insights in the renal phenotype of cystic fibrosis. Pflugers Arch. 2009;457(6):1227-36.

10. Castile R, Shwachman H, Travis W, Hadley CA, Warwick W, Missmahl HP. Amyloidosis as a complication of cystic fibrosis. Am J Dis Child. 1985;139(7):728-32.

11. Stephens SE, Rigden SP. Cystic fibrosis and renal disease. Paediatr Respir Rev. 2002;3(2):135-8.

12. Al-Shawwa BA, Rao AR. Cystic fibrosis and renal disease: a case report. J Med Case Reports. 2007;1:24.

13. Gaffney K, Gibbons D, Keogh B, FitzGerald MX. Amyloidosis complicating cystic fibrosis. Thorax. 1993;48(9):949-50.
14. Melzi ML, Costantini D, Giani M, Appiani AC, Giunta AM. Severe nephropathy in three adolescents with cystic fibrosis. Arch Dis Child. 1991;66(12):1444-7.

15. National Kidney Foundation. K/DOQ1 clinical practice guidelines for chronic kidney disease: evaluation, classification, and stratification. Am J Kidney Dis. 2002;39(2 Suppl 1):S1-266.

16. Keane WF, Eknoyan G. Proteinuria, albuminuria, risk, assessment, detection, elimination (PARADE): a position paper of the National Kidney Foundation. Am J Kidney Dis. 1999;33(5):1004-10.

17. Guidelines for the management of proteinuria. Indian J Nephrol. 2005;15(Suppl 1):S7-S9.

18. Corey M. Modelling survival in cystic fibrosis. Thorax. 2001;56(10):743.

19. Moorcroft AJ, Dodd ME, Webb AK. Exercise testing and prognosis in adult cystic fibrosis. Thorax. 1997;52(3):291-3.

20. Schluchter MD, Konstan MW, Drumm ML, Yankaskas JR, Knowles MR. Classifying severity of cystic fibrosis lung disease using longitudinal pulmonary function data. Am J Respir Crit Care Med. 2006;174(7):780-6.

21. Wilschanski M, Zielenski J, Markiewicz D, Tsui LC, Corey M, Levison $\mathrm{H}$, et al. Correlation of sweat chloride concentration with classes of the cystic fibrosis transmembrane conductance regulator gene mutations. J Pediatr. 1995;127(5):705-10.

22. Cemlyn-Jones J, Gamboa F, Loureiro M, Fontes Baganha M. Evaluation of bone mineral density in cystic fibrosis patients. Rev Port Pneumol. 2008;14(5):625-34.

23. Davis CA, Abramowsky CR, Swinehart G. Circulating immune complexes and the nephropathy of cystic fibrosis. Hum Pathol. 1984;15(3):244-7.

24. Dobson L, Stride A, Bingham C, Elworthy S, Sheldon $\mathrm{CD}$, Hattersley AT. Microalbuminuria as a screening tool in cystic fibrosis-related diabetes. Pediatr Pulmonol. 2005;39(2):103-7.

25. Dalcin Pde T, Abreu E, Silva FA. Cystic fibrosis in adults: diagnostic and therapeutic aspects. J Bras Pneumol. 2008;34(2):107-17.

26. Cystic Fibrosis Foundation. Patient Registry 2002 Annual Data Report. Bethesda: CFF; 2003.

27. Nash KL, Allison ME, McKeon D, Lomas DJ, Haworth CS, Bilton D, et al. A single centre experience of liver disease in adults with cystic fibrosis 1995-2006. J Cyst Fibros. 2008;7(3):252-7

\section{About the authors}

\section{Jessica Cemlyn-Jones}

Resident of Pulmonology in the Department of Pulmonology and Allergology of the Hospitals of the University of Coimbra, Coimbra, Portugal.

\section{Fernanda Gamboa}

Pulmonology Consultant in the Department of Pulmonology and Allergology of the Hospitals of the University of Coimbra, Coimbra, Portugal. 